\title{
初期の歯石についての生物学的研究
}

第 2 報 初期の歯石の石灰化能について

\author{
新谷英章 \\ 東京医科歯科大学第 2 歯科保存学教室（指導 : 木下四郎教授）
}

（昭和 45 年 1 月 30 日受付）

\section{Biological Studies on Early Dental Calculus.}

2. Calcifying ability of early dental calculus

\author{
Hideaki Shintani \\ Department of Periodontology, School of Dentistry \\ Tokyo Medical and Dental University \\ (Director : Prof. Shiro Kinoshita)
}

要旨 歯垢や歯石と歯周疾患の発生との間に, 臨床的実験および疫学的観察などから, 高い相関 関係がみられることは明らかである。今日まで数多くの歯垢や歯石についての研究が報告されてい るが，まだその形成機序や石灰化について不明な点がいろいろと残されている。

本実験は Standardized foil technique を応用して, 歯石形成量の個体差は何に起因するのかを解 明し, 歯石の形成機序についての手がかりを得るために, アイソトープ Calcium-45 をトレーサー として, 初期の歯石の石灰化能について検索した。

臨床的に正常な歯列と歯肉をもつ, 被験者 5 人の下顎中切歯の舌側に規格化した foil を装着し, その上に 3 日間と 6 日間に堆積する歯石を集めた。

歯石形成速度は 6 日間についてだけ調べた。個体間には有意の差がみられたが， 2 回の期間の間， および左側と右側中切歯の間には有意の差はなかった。

石灰化能については, foil 上に堆積した沈着物を口腔内より取り出すと,ただちに生理的食塩水 に保存し, その後 $\mathrm{Ca}^{45}$ を含む石灰液中に 2 時間浸漬し, 沈着物の $\mathrm{Ca}^{45}$ の取り込み量を Gas flow counter を用いて，5分間測定した。

$\mathrm{Ca}^{45}$ は $10 \mu \mathrm{c} / \mathrm{ml}$ の濃度のものを用い, 浸漬液は Calcifying solution $2 \mathrm{cc} に \mathrm{Ca}^{45}$ を $0.2 \mathrm{cc}$ 混 合したものである。

6 日間に foil 上に堆積した沈着物の量は個体によって差がみられたが，同一の個体から同じ方法 を用いて採取した 3 日目と 6 日目の沈着物の石灰化能には個体間の 差がみられなかった。しかも， 統計学的には両者の間に相関関係が認められなかった。また, 3 日目の沈着物の $\mathrm{Ca}^{45}$ の取り込み 量については, 3 回の期間の間, および下顎の左右中切歯間に有意の差はなかった。

6 日目の沈着物の石灰化能は 3 日目のものより, 測定值で約 6 割増加していた。

以上の結果について, 考察を加えた。 


\section{緒 言}

歯垢や歯石と歯周疾患との間に， 臨床的実験 ${ }^{1)}$ および疫学的観察 2)31 などから，高い相関関係が みられることは明らかである。したがって，歯垢 と歯石の問題は今日でも，なお歯周疾患の病因を 考える上に最も重要なものである。今日まで数多 くの歯垢や歯石についての研究が 報告されている が，まだその形成機序や石灰化 (Calcification) に ついては不明な点がいろいろと残されている。こ の点を解明するために初期の歯石の石灰化の状態 についての質的な研究が多くなされている。すな わち組織学的には光学顕微鏡 ${ }^{4) 5)}$ や電子顕微鏡(6) 7)

によるいくつかの詳細な観察があり，さらに Microradiography $^{8)}$ やX 線回折 ${ }^{9)}$ による報告も行なわ れている。しかしながら，歯垢や歯石の形成につ いて，量的にみた研究は必ずしも多くない。これ らは歯石中の灰量や無機成分 ${ }^{10-13)}$ を定量的に測 定して，石灰化の状態を観察しているのが大部分 である。

歯石を定量的に集めるための一方法として Standardized foil technique (foil 法) が考案 ${ }^{14}$ さ れ，この方法によって一定期間に形成される歯石 の乾燥重量 (Dry deposit weight) が歯石形成速 度 (Rate of calculus formation) と名付けられ $た^{15)}$ 。歯石形成速度については，個体間に有意の 差がみられることが知られており，第 1 報でも報 告した ${ }^{16)}$ 。すなわち，成人において同じような生 活環境にありながら, 歯石の沈着しやすいヒトと 沈着しにくいヒトがいることが明らかにされた。

本実験はこの歯石形成量の個体差は何に起因す るのかを解明し，歯石の 形成機序についての手が かりを得るために試みた。foil 法を応用して歯石 を採取し，アイソトープ Calcium-45を tracer として, 初期の歯石の石灰化能について検索し た。

\section{実験材料と方法}

1. 被験者について

被験者として, 臨床的に正常な歯列と歯肉をも
つ, 24 歳から 26 歳の 東京医科歯科大学歯学部の男 子学生 5 人を選んだ。

\section{2. 初期歯石の採取法}

歯石を採取する方法として，規格化した厚さ $0.051 \mathrm{~mm}$, 一辺の長さ $7 \mathrm{~mm}$, 表面積約 $29 \mathrm{~mm}^{2}$ の 二等辺三角形の foil を応用した (foil 法)。すな わち foil を第 1 報の如く化学的洗浄, 乾燥して, 被験者の下顎中切歯の舌側に装着し, foil 上に堆 積した沈着物を初期歯石とした。実験期間中その 部位への歯ブラシの使用を禁止したが，食事その 他の制限は一切与えなかった。

3. 浸漬液 (Incubation solution)

この実験のために使用した Calcifying solution の組成は次のようなものである。

$$
\mathrm{Ca}-2 \mathrm{mM}\left(\mathrm{CaCl}_{2}\right)
$$$$
\mathrm{P}-3 \mathrm{mM}\left(\mathrm{NaH}_{2} \mathrm{pO}_{4}\right)
$$

$\mathrm{pH}$ は $\mathrm{NaOH}$ を用いて, 7.1に調節した。この 溶液を冷室に保存しておき, 各実験の毎に $\mathrm{pH}$ の checkを行なった。

歯垢の石灰化を in vitro で観察した報告は数多 くあり，それに用いた Calcifying solution にも いろいろな組成のものが考えられているが，ここ では上記のものを用いた。これは比較的安定なの で，再現性も高く，本実験の目的に適していると 考えたためである。

トレーサーとして使ったアイソトープ Calcium45 は濃度 $10 \mu \mathrm{c} / \mathrm{ml}$ のものを用いた。

浸漬液は Calcifying solution $2 \mathrm{cc}$ に $\mathrm{Ca}^{45}$ を $0.2 \mathrm{cc}$ 混合したものである。

4. $\mathrm{Ca}^{45}$ の测定

$\mathrm{Ca}^{45}$ の測定に使用した Gas flow counter は日 本無機医理学研究所の製作した counter $(2 \pi$ 型) でQガスを使用し，空無しで用いた。

測定時間は予備実験から 5 分間とした。すなわ ち，5分間に放出したアイソトープの count 数を もって測定值とした。

5. foil 上に堆積した 沈着物による $\mathrm{Ca}^{45}$ の取 り込みについて

5 人の被験者の口腔内より foil とともに日齢 3 日と 6 日の沈着物を取り出し，ただちに生理的食 
塩水に保存した。この沈着物を $\mathrm{Ca}^{45}$ の入った浸 漬液中に室温で 2 時間浸漬した。 2 時間後に 沈着 物を取り出し, $\mathrm{Ca}^{45}$ を含まない Calcifying solution で洗浄した後に放射能測定用の試料血に移 し，1時間赤外線ランプで乾燥した。乾燥の終っ た foil と沈着物を新らしい試料皿に移し, 沈着物 の堆積していない foil の面をセメダインで貼りつ けて, gas flow counter に入れて $\mathrm{Ca}^{45}$ の放射能 を測定した。

日齢 3 日と 6 日の foil 上に堆積した沈着物によ る $\mathrm{Ca}^{45}$ の取り込み量をそれぞれ 3 回と 2 回測定 した。

foil 自身による $\mathrm{Ca}^{45}$ の取り込みを観察するた めに, 通常の如く化学的洗浄を施し, 乾燥した foil 15枚を $\mathrm{Ca}^{45}$ の入った浸漬液に入れ，2 時間 浸漬を行なった。2 時間後に foil を取り出し, 同 様にして放射能の測定を行ない，その值を対照と して表 1 に示す。

\begin{tabular}{ccc} 
表 1 & $\begin{array}{l}\text { foil 自身による } \mathrm{Ca}^{45} \\
\text { 取り込み量( } 5 \text { 分間) }\end{array}$ \\
3443 & 3870 & 3914 \\
4506 & 4942 & 4925 \\
5440 & 5497 & 5824 \\
5953 & 6568 & 6952 \\
8584 & 8999 & 9018 \\
\multicolumn{3}{c}{$\overline{\mathrm{x}}=5895.7 \pm 1709.8$}
\end{tabular}

表1のように foil 自身による $\mathrm{Ca}^{45}$ の取り込み もみられた。しかし，その值を foif と沈着物によ る $\mathrm{Ca}^{45}$ の取り込みの值と比較すると，1/100以 下となり無視できるものと思われる。

\section{6. 浸漬時間}

浸漬時間を定めるために, 次のような 予備実験 を行なった。時間を 2 時間と 24 時間に定め, foil に堆積した沈着物の $\mathrm{Ca}^{45}$ による取り込み量の差 を測定した。

3 人の被験者の下顎中切歯の舌側に 堆積した日 龄 3 日の沈着物を foil 法で採取し，これを浸漬液 に入れて，一方を 2 時間，他方を 24 時間浸漬し， 取り込まれた $\mathrm{Ca}^{45}$ を測定した。その值を表 2 に 示す。
表 2 foil 上に堆積した日齢 3 日の沈着物の $\mathrm{Ca}^{45}$ の取り込み量 ( 5 分間)。“浸漬時 間 ( 2 時間, 24 時間)の違いによる影響”

\begin{tabular}{c|c|c}
\hline Time & 2h. & $24 \mathrm{~h}$. \\
\hline Subjects & 129941 & 148716 \\
A & 146407 & 167352 \\
\hline B & 113210 & 112140 \\
& 99762 & 86413 \\
\hline \multirow{2}{*}{ C } & 128841 & 128324 \\
& 108140 & 158403
\end{tabular}

第 1 報 ${ }^{16)}$ で，下顎前歯の舌側に装着した foil 上 に堆積した沈着物には, 左右の中切歯間に 沈着量 の有意差がないことがみられた。

したがって, 同一人の左右の沈着物を取り替え て繰り返して 2 回浸漬を行なった。

この結果から，2 時間值と 24 時間值による著明 な差がみられないことがわかったので，浸漬の時 間を 2 時間とした。

\section{7. 歯石の形成速度}

初期の歯石の形成量を知るために, 次のような 観察をした。5 名の被験者の下顎中切歯の舌側に, 化学的に洗浄をした foil を 6 日間装着した。6日 後に foil を取り出し, $110^{\circ} \mathrm{C}$ で 3 時間乾燥し, 日齢 6 日の歯石の乾燥重量とした。6 日間の実験 を 2 回繰り返して行なった。

\section{結果}

\section{1）歯石形成速度}

下顎中切歯の舌側に堆積した日齢 6 日の歯石の 乾燥重量を表 3 亿示す。

日齢 6 日の歯石の乾燥重量の平均值とその標準 偏差は一歯当り, 右側中切歯が $488.3 \pm 127.4 \mu \mathrm{g}$, 左側が $572.7 \pm 185.3 \mu \mathrm{g}$ であった。

これらの值について, 分散分析法によって調べ ると，個体間には危険率 0.01 で有意の差があっ た。2 回の期間の間, および左側中切歯と右側中 切歯の間には危険率 0.01 で有意の差がなかった (表 4)。
2) $\mathrm{Ca}^{45}$ の取り込み 
表 3 下顎中切歯に装着した foil の上に堆積した日齢 6 日の沈着物の乾燥重量 $(\mu \mathrm{g})$

\begin{tabular}{|c|c|c|c|c|c|c|}
\hline Subjects & $\mathrm{A}_{5}$ & $\mathrm{~A}_{2}$ & $\mathrm{~A}_{3}$ & $\mathrm{~A}_{4}$ & $\mathrm{~A}_{5}$ & Mean \\
\hline Periods tions & $\mathrm{L}$ & $\mathrm{L}$ & $\mathrm{R}$ & $\mathrm{R}$ & $\mathrm{R}$ & $\mathrm{R}$ \\
\hline I & $4011064^{663}$ & ${ }_{1262}^{764}$ & $378707^{329}$ & $521{ }_{1057}^{536}$ & ${ }^{714}{ }_{1437}^{723}$ & $\begin{array}{c}502.4 \quad 603.0 \\
1105.4\end{array}$ \\
\hline II & $342 \quad 8599^{517}$ & $532{ }_{1305} 773$ & $301512{ }^{211}$ & $602{ }_{1256}^{654}$ & $544{ }_{1101} 557$ & $\begin{array}{c}464.2542 .4 \\
\quad 1006.6\end{array}$ \\
\hline Mean & $\begin{array}{c}371.5590 .5 \\
961.5\end{array}$ & $\begin{array}{c}515.0768 .5 \\
1283.5\end{array}$ & $\begin{array}{c}339.5 \quad 270.0 \\
609.5\end{array}$ & $\begin{array}{c}561.5 \quad 595.0 \\
1156.5\end{array}$ & $\begin{array}{c}629.0 \quad 640.0 \\
1269.0\end{array}$ & $\begin{array}{c}483.3 \quad 552.7 \\
1036.0\end{array}$ \\
\hline
\end{tabular}

下顎中切歯の舌側に装着した foil 上に堆積した 日齢 3 日の沈着物による $\mathrm{Ca}^{45}$ の取り込み量を個 体および期間別に表 5 に示す。

下顎の右側中切歯に装着した foil 上に堆積した 日齢 3 日の沈着物に取り込まれる $\mathrm{Ca}^{45}$ の測定值 とその 標準偏差は 1 歯当り $131538 \pm 47022$ であ り，左側のそれは $120386 \pm 39348$ であった。1歯 当り，平均 $125962 \pm 42977$ だった。個体間に有意
表 4 表 3 の分散分析表

\begin{tabular}{l|r|r|r}
\hline \multicolumn{1}{c|}{ Source of Variation } & Df & \multicolumn{1}{c|}{ SS } & \multicolumn{1}{|c}{ MS } \\
\hline Subjects & 4 & 315518 & $78879.5^{* *}$ \\
L. vs. R. incisors & 1 & 12201.8 & 12201.8 \\
Sub. x L. vs. R. incisors & 4 & 46397.2 & 11599.3 \\
Remainder & 10 & 120893 & 12089.3 \\
\hline & 19 & 495010 & 26053.2
\end{tabular}

表 5 foil 上に堆積した日齢 3 日の沈着物に取り込まれた $\mathrm{Ca}^{45}$ の測定值（5 分間）

\begin{tabular}{|c|c|c|c|c|c|c|c|c|c|c|}
\hline \multirow{2}{*}{$\sum_{\text {Periods }}^{\text {Subjects }}$ Posi- } & \multicolumn{2}{|c|}{$A_{1}$} & \multicolumn{2}{|c|}{$\mathrm{A}_{2}$} & \multicolumn{2}{|c|}{$\mathrm{A}_{3}$} & \multicolumn{2}{|c|}{$\mathrm{A}_{4}$} & \multicolumn{2}{|c|}{$\mathrm{A}_{5}$} \\
\hline & $\mathrm{R}$ & L & $\mathrm{R}$ & L & $\mathrm{R}$ & $\mathrm{L}$ & $\mathrm{R}$ & L & $\mathrm{R}$ & L \\
\hline I & 62181 & 113350 & 170594 & 123461 & 188230 & 180512 & 218387 & 188010 & 121346 & 173031 \\
\hline II & 54485 & 81225 & 153364 & 133358 & 105321 & 73700 & 94804 & 126823 & 167640 & 154264 \\
\hline III & 101708 & 65545 & 111956 & 80416 & 157647 & 100126 & 95101 & 114823 & 160304 & 97141 \\
\hline Mean & 72791 & 86767 & 145305 & 112412 & 150399 & 118113 & 136097 & 143219 & 153219 & 141479 \\
\hline
\end{tabular}

差があるかどうかを分散分析法で調べると，危険 率0.01で有意の差は認められなかった(表 6 )。

3 回の期間, 下顎の左, 右中切歯間には, 危険 率0.01で有意の差は認められなかった。

なお，測定值の下 2 桁は信頼性が 薄いと考えら れるので, 統計的検定には下 2 桁を 四捨五入した ものを用いて行なった。

同様に測定した日齢 6 日の沈着物による $\mathrm{Ca}^{45}$ の取り込み量を表 7 に示す。これによると，右側 中切歯による取り込みは $224517 \pm 50251$, 左側は $187318 \pm 18366$ ，一歯当り $205917 \pm 54924$ であっ
表 6 表 5 の分散分析表

\begin{tabular}{l|r|r|r}
\hline \multicolumn{1}{c|}{$\begin{array}{c}\text { Source of } \\
\text { Variation }\end{array}$} & Df & \multicolumn{1}{c|}{ SS } & \multicolumn{1}{c}{ MS } \\
\hline Subjects & 4 & 17122.49 & 4280.62 \\
L. vs. R. incisors & 1 & 932.98 & 932.98 \\
Sub. x L. vs. R. & 4 & 2819.62 & 704.91 \\
incisors & 20 & 32688.95 & 1643.45 \\
Remainder & 29 & 53564.04 & 1847.04
\end{tabular}

た。分散分析法で調べると個体間および左右中切 歯間に危険率 0.01 で有意の 差は認められなかっ た。以上の結果から， 6 日目の沈着物の $\mathrm{Ca}^{45}$ の 
表 7 日齢 6 日の沈着物に取り込まれた $\mathrm{Ca}^{45}$ の測定値 ( 5 分間)

\begin{tabular}{|c|c|c|c|c|c|c|}
\hline Positions Subjects & $\mathrm{A}_{1}$ & $\mathrm{~A}_{2}$ & $\mathrm{~A}_{3}$ & $\mathrm{~A}_{4}$ & $A_{5}$ & Mean \\
\hline Right incisors & 222356 & 184404 & 180903 & 305517 & 229405 & 224517 \\
\hline Left incisors & 129578 & 202088 & 164346 & 160124 & 280452 & 187318 \\
\hline Mean & 175967 & 193246 & 172625 & 232821 & 254929 & 205917 \\
\hline $\begin{array}{l}\text { Sub. } \\
\text { H. } \\
\text { F. } \\
\text { Y. } \\
\text { Y. } \\
\text { T. }\end{array}$ & ts $\begin{array}{r}\text { D. D. W. } \\
(609.5) \\
(961.5) \\
(1156.5) \\
(1269.0) \\
(1283.5)\end{array}$ & $\begin{array}{l}\text { Subjects } \\
\text { F.T. } \\
\text { T.S. } \\
\text { H.S. } \\
\text { Y.K. } \\
\text { Y.S. }\end{array}$ & $\begin{array}{c}\text { 日命 } 3 \text { 日 } \text { 日 }^{45} \text { 出 } \\
\text { 取り 込2量 } \\
(159.5) \\
(257.8) \\
(268.5) \\
(279.3) \\
(294.5)\end{array}$ & $\begin{array}{l}\text { Subjects } \\
<_{\text {H. S. }} \\
\text { F. T. } \\
\text { T. S. } \\
\text {-Y. K. } \\
\text {-Y.S. }\end{array}$ & $\begin{array}{c}\text { 日令6 日のCa } \\
\text { 取り込み量 } \\
(345.2) \\
(351.9) \\
(386.5) \\
(465.6) \\
(509.9)\end{array}$ & \\
\hline
\end{tabular}

図 1 歯石の乾燥重量 $\left(\mathrm{D} \cdot \mathrm{D} . \mathrm{W}\right.$.) と $\mathrm{Ca}^{45}$ の取り込み量との関係

取り込み量は 3 日目のものよりも測定值で, 約 6 割も増加していた。

3）歯石の形成量と $\mathrm{Ca}^{45}$ の取り込み量との関 係

下顎中切歯の舌側に装置した foil に堆積した沈 着物の量とその沈着物中に取り込まれた $\mathrm{Ca}^{45}$ の值 との間の相関関係について検討をした。

3 日と 6 日の沈着物による $\mathrm{Ca}^{45}$ の取り込み量 と 6 日間に堆積した沈着物の乾燥重量との間の相 関係数 $\gamma$ は，それぞれ $0.15,0.24$ となり,この $\gamma$ を検定すると, Fcal (; F cal $\left.=\frac{(\mathrm{N}-2)}{1-\gamma^{2}}-\gamma^{2}\right)$ はそれぞ れ0.18と0.49となった。その結果 $\mathrm{F}_{8}^{1}(0.05), \mathrm{F}_{8}^{1}$ $(0.01)>0.18,0.49$ となり, 両者の間には有意の 相関は認められなかった

歯石の乾燥重量と $\mathrm{Ca}^{45}$ の取り込み量との間に, 統計学的には相関関係はなかったが, 両者の関係 を図 1 で示す。

左側に日齢 6 日の乾燥重量の少ない順に個体を ならべた。右側に日齢 3 日と 6 日の沈着物による $\mathrm{Ca}^{45}$ の取り込み量を少ない順にならべ, 左側と右 側の対応する個体を線でむすんで図示した。

\section{考案}

歯垢が in vitro で石灰化を起こすかどうかを 調べるために, 次のような別の予備実験を行なっ た。
口腔内より取り出した歯垢をスライド・グラス に塗りつけ, calcifying solution に入れ, $37^{\circ} \mathrm{C} て ゙$ 7 日間培養を行なった。

実験の前後に，同一部位を同培率の 偏光顕微鏡 を用いて，石灰化の状態を観察した。図 2 は培養 前の状態で, すでに部分的には石灰化がおこって いる。図 3 は培養後の状態を示す。複屈折が認め られ, 白くみえる領域に石灰化がおこっているこ とが証明された。このような報告は他にもすでに いくつかあるが ${ }^{18)}$, 以上の結果から in vitro でも 歯垢の石灰化が進むことは明らかであるように思 われた。

初期の歯石を定量的に集める方法として, Standardized foil technique が有効なことが第 1 報で 分ったので, 本実験の資料の採取にもこの方法を 応用した。

下顎前歯の舌側に装着した foil 上に，6 日間に 堆積した沈着物の乾燥重量は, 同じ方法を用い

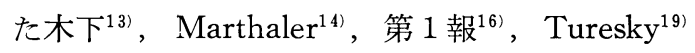
らの $7 \sim 8$ 日の值よりも,わずかに低い值だっ た。この乾燥重量は前報の結果と同様に, 個体間 に有意の差が認められた。この原因について、い ままでの報告から考えられることはすでに第 1 報 ${ }^{16)}$ で考察した。

foil 上に， 3 日間と 6 日間に堆積した沈着物の $\mathrm{Ca}^{45}$ の取り込み量については個体差が認められな かった。 


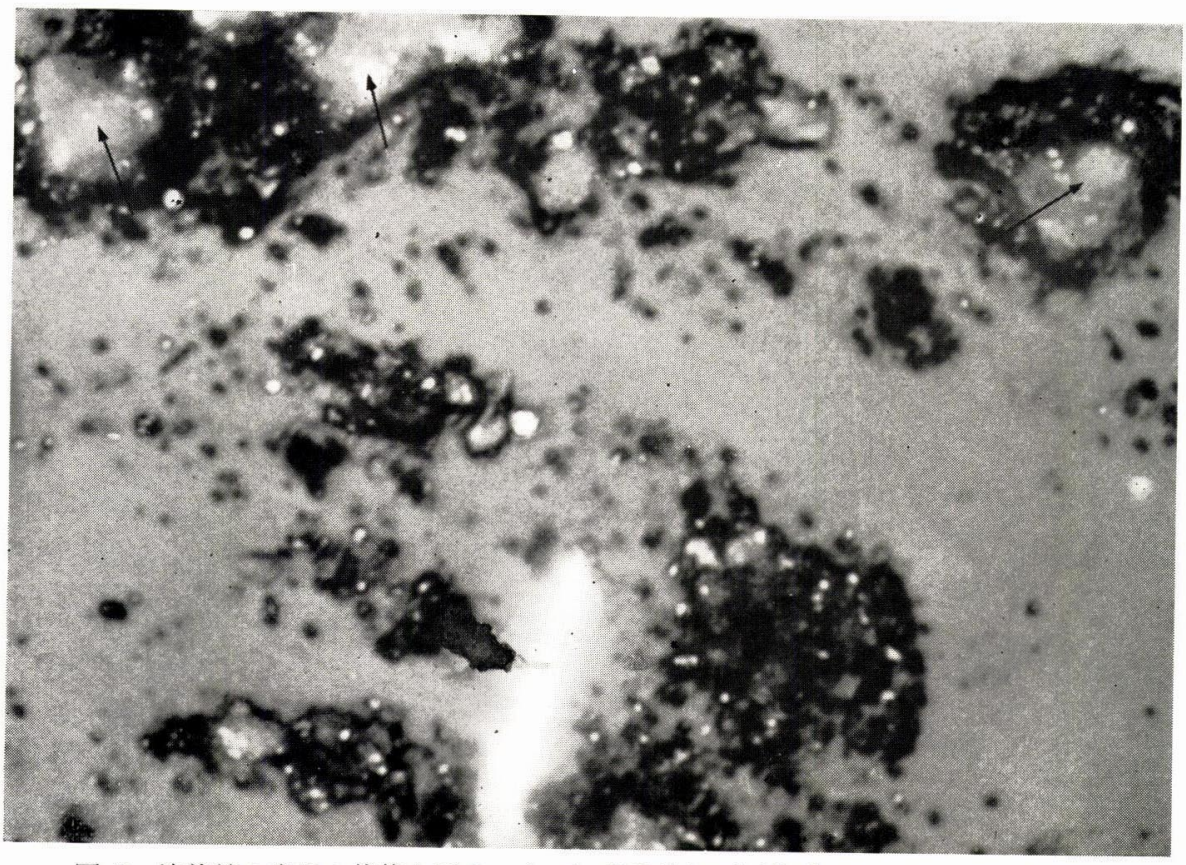

図 2 培養前の歯垢の状態を示す。すでに部分的に石灰化がおこっている。(

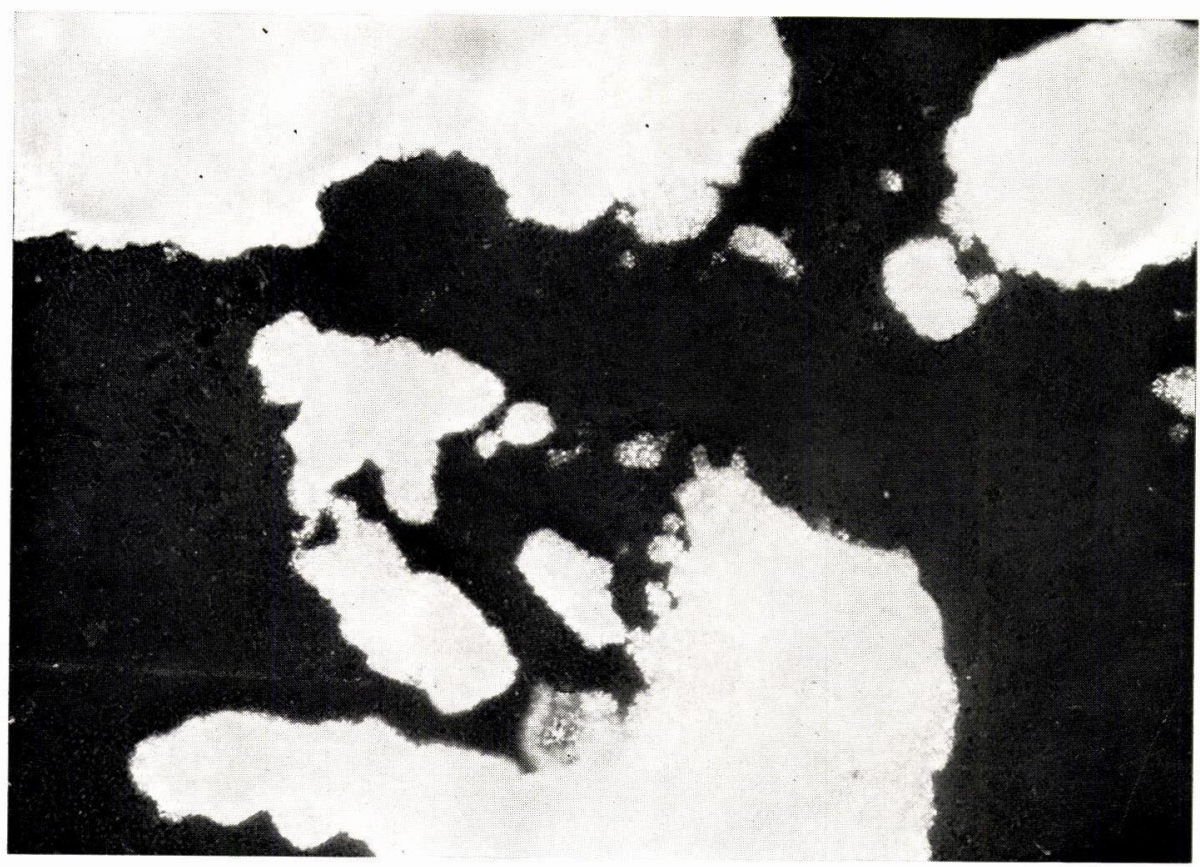

図 3 培養後の状態を示す。複屈折した部分が白くみえ, 石灰化したことを示す。（×70） 
さらに, 乾燥重量と沈着物による $\mathrm{Ca}^{45}$ の取り 込み量との間には相関関係はみられなかった。

これらの点について 2,3 の考察を加えてみた w。

3 日間に堆積した沈着物について $\mathrm{Ca}^{45}$ の取り 込みを観察したのは，下顎前歯の舌側に堆積する 沈着物は $2 ， 3$ 日中に石灰化することが 初期の歯 石についての研究10) で知られているからである。

すなわち, 日齢 3 日の沈着物中の灰量は, 乾燥 重量の約 $41 \%{ }^{20)}$ であった。

Schroeder ${ }^{10)}$ によると, 歯石の形成しやすいヒト では 2 日目で，すでに Ca. P 含有量がかなり高く なることが知られている。

一方，歯石の採取法は異なるけれども，Scharawy $^{211}$ は歯石の形成しにくいヒトでは，2 日目で 灰量が最大になり，それ以後は量的にあまり変化 しないことを報告している。

また, celluloid strips に堆積した日齢 4 日の沈 着物は, さらに石灰化液中で培養すると石灰化が 進行することが soft X-ray や組織学的な観察に

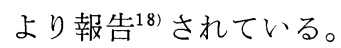

以上の報告から，3 日目位の歯石にはかなり強 い石灰化能があるものと推定された。

したがって, 本実験では石灰化能を測定する日 をまず 3 日目とし，続いて 6 日目の資料で測定し た。歯石形成速度は 6 日目の沈着物で観察した。

3 日目の乾燥重量を測定して, 歯石形成速度を調 ベることは，測定誤差が大きくなることが明らか にされている(10)ので, 歯石形成速度は 6 日目の資 料についてのみ測定した。6 日目の沈着物の石灰 化能の活性が，3 日目のものより高くなっている ことは興味ある新らしい知見であった。

これらは細菌の量や組成および石灰化の核にな りうる物質が増加したことによるものと考えられ る。

事実, $1 \sim 2$ 日目の歯垢に球菌や桿菌が多く, $2 \sim 4$ 日では紡錘菌や線状微生物が多くなり, 4 〜9日目ではスピロヘータおよびラセン菌の占め る割合が多くなってくることが報告 ${ }^{22)}$ されている ことからして, 細菌の役割がまず考えられる。し
かし, Schroeder らの観察によると, 細菌体の他 に細菌体外にも石灰化がおこるらしいこと，およ び無菌動物にも歯石様物質の沈着がみられる報 告 ${ }^{23)}$ 24) な゙から考察すると, 単に細菌のみの影響 とだけと考えにくい点もある。

そこで，唾液の影響について考えると，唾液の 性状に個体差があることは知られており，唾液と 歯石との間に密接な関係があることも報告 ${ }^{25) 26)}$ れている。すなわち, in vitro の実験で, 歯石様 物質が唾液から作られること 27728)，唾液腺を取っ た動物に，歯石形成がおこらないこと年3 30) などの 報告から推察しても, 唾液環境の影響が大きいこ とが考えられる。Eilberg ら ${ }^{311}$ は唾液中の nucleating substance について, $\mathrm{Ca}^{45}$ を用いて実験を行 ない，石灰化を誘導する核の存在を暗示してい る。

6 日間に foil 上に堆積した沈着物の量は個体に よって差がみられたが，同一の個体から同様にし て採取した 3 日目と 6 日目の沈着物の石灰化能に は個体間の差がみられなかった。しかも, 両者の 間には統計学的に相関関係が認められなかった。 その理由については, 資料の浸漬を常温で行なっ たこと，および石灰化液の 影響なども考えられる が，今回の実験では解明できなかった。このこと は興味ある問題と思われるので, 今後さらに培養 条件や石灰化液の組成を変えて追求して行きた w。

本実験注被験者の数が十分であるとは考えにく いが, 初期の沈着物の石灰化能の活性についてし らべ，1，2の興味ある結果を得た。このような 報告は今までにみられない。

今後は, 歯石の 沈着しにくいヒトについても, 同様な石灰化能を検索し，さらに沈着物の 経時的 変化による石灰化能の検討を加えて究明したい。

\section{結論}

臨床的に正常な歯列をもち，歯肉炎を有しない 5 人の男子学生について, 下顎中切歯の舌側に規 格化した foil を装着し, その上に堆積する歯石を 集めて, 歯石形成速度と初期の歯石の石灰化能に 


\section{ついて観察した。}

下顎中切歯の舌側に沈着した日齢 6 日の歯石の 乾燥重量は 1 歯当り $528.0 \pm 161.4$ であった。歯石 の形成量は個体間に有意の差があった。下顎中切 歯の舌側に装着した foil 上に 3 日および 6 日間に 堆積した沈着物の石灰化能をみるために, 沈着物 をアイソトープ Calcium-45 を含む溶液中に浸漬 し, 沈着物の $\mathrm{Ca}^{45}$ の取り込み量を Gas flow counter を用いて測定した。

3 日間に堆積した沈着物による $\mathrm{Ca}^{45}$ の取り込 み量と 6 日間に堆積した沈着物による $\mathrm{Ca}^{45}$ の取 り込み量とを比較すると，6日目の沈着物の石灰 化能は 3 日目のものより, 測定值で約 6 割高かっ た。

統計的処理を行なうと，3 日目の沈着物による $\mathrm{Ca}^{45}$ の取り込み量については個体間に，3 回の期 間の間に，および下顎の左右中切歯間に有意の差 はなかった。 6 日目の沈着物による $\mathrm{Ca}^{45}$ の取り 込み量についても，個体間にも有意の差はなかっ た。下額中切歯の舌側に堆積した沈着物の石灰化 能と乾燥重量との間には相関関係が認められなか った。

稿を終るにさいし，終始御懇篤なる御指導と御校閲を 賜った木下四郎教授, 歯学部生化学教室の佐々木教授に 深く感謝いたします。また御協力いただいたアイソトー プ室の藤井技官, 当教室の末田武講師, 鈴木康司講師, 保存学教室の各位に御礼申し上げます。

\section{文献}

1) Löe, H., Theilade, E. and Jensen, S. B. : Experimental gingivitis in man. J. Periodont., $36: 177,1965$.

2) Russell, A. L. : Epidemiology of periodontal disease. Internat. dent. J., $17: 282,1967$.

3）石川純，山崎敬介：野生および飼育ニホンザル の口腔内所見の比較, 日本歯槽膿漏学会誌, 6 : 38, 1964.

4) Mandel, I. D., Levy, B. M. and Wasserman, B. H. : Histochemistry of calculus formation. J. Periodont., 28 : 132, 1957.

5) Schroeder, H. E., Lenz, H. and Mühlemann, H. R. : Mineralization centers in early dental calculus by light and electron microscopy. Helv. Odont. Acta, 7 : 67, 1963.
6) Schroeder, H. E. : Two dinfferent types of mineralization in early dental calculus. Helv. Odont. Acta, 8 : 117, 1964.

7) Schroeder, H. E., Lenz, H. and Mühlemann, H. R. : Microstructures and mineralization of early dental calculus. Helv. Odont. Acta, $8: 1,1964$.

8）増田正樹： Microradiography によるセメント 質および歯石の研究, 口病誌, $32: 82,1962$.

9) Schroeder, H. E. and Bambauer, H. V. : Stages of calcium phosphate crystallization during calculus formation. Arch. Oral Biol., $11: 1,1966$.

10) Schroeder, H. E. : Inorganic content and histology of early dental calculus in man. Helv. Odont. Acta, $7:$ 17, 1963.

11) Gr $\phi$ n, P. and van Campen G. J. : Mineral composition of human dental calculus. Helv. Odont. Acta, $11: 71,1967$.

12) Little, M. F., Casciani, C. A. and Rowley, J. : Dental calculus composition. I. Supragingival calculus: ash, calcium, phosphorus, sodium and density. J. dent. Res., 42 : 78, 1963.

13) Kinoshita, S. and Mühlemann, H. R. : Effect of sodium ortho- and pyrophosphate on supragingival calculus. Helv. Odont. Acta., 10 : 46, 1966.

14) Marthaler, T. M., Schroeder, H. E. and Mühlemann, H. R. : A method for the quantitative assessment of plaque and calculus formation. Helv. Odont. Acta, 5 : 39, 1961.

15) Mühlemann, H. R. and Schroeder, H. E. : Dynamics of supragingival calculus formation. (Staple: Advances in oral biology 1 : 175, Academic Press, New York and London, 1964).

16）新谷英章 : 初期の歯石についての生物学的研究. 第 1 報 歯石の採取法, 歯石形成速度および歯 石の成分について，口病誌，35:189，1968.

17）佐久間昭：生物検定法, 東京, 1964, 東大出版 会, 128 .

18) Wasserman, B. H., Mandel, I. D. and Levy, B. M. : In vitro calcification of dental calculus. J. Periodont., 29 : 144, 1958.

19) Turesky, S., Gilmore, N. D. and Glickman, I. : Calculus inhibition of topical application of the chlorometyl analogue of Victamine C. J. Periodont., 38 : 2, 1967.

20) Mandel, I. D. : Dental plaque: Nature, formation and effects. J. Periodont., $37: 357$, 1966.

21) Schrawy, A. M., Sabharwal, K., Socransky, 
S. S. and Lobene, R. R. : A quantitative stu$\mathrm{dy}$ of plaque and calculus formation in normal and periodontally involved mouths. J. Periodont., 37 : 495, 1966.

22) Theilade, E., Wright, W. H., Jensen, S. B. and Löe, H. : Experimental gingivitis in man. II. A longitudinal and clinical and bacteriological investigation. J. Periodont., Res. $1: 1,1966$.

23) Glas, J. E. and Krasse, B. : Biophysical studies on dental calculus from germfree and conventional rats. Acta Odont. Scand., 20 : 127, 1962.

24) Theilade, J., Fitzgerald, R. J., Scott, D. B. and Nylen, M. V.: Electron microscopic observations of dental calculus in germfree and conventional rats. Arch. Oral Biol., 9 : 97, 1964.

25) Mandel, I. D. : Histochemical and biochemical aspects of calculus formation. Periodontics, $1: 43$, 1963.
26) Stanford, J. W.: Analysis of organic portion of dental calculus. J. dent. Res., 45 : $128,1966$.

27) Fehr, F. and Brudevold, F. : In vitro calculus formation. J. dent. Res., 39 : 1041, 1960.

28) Yankelowitz, S., Weiss, S., Gould, D. H. and Altarelli, V. R. : A method and apparatus for studying in vitro calculus. J. dent. Res., $44: 648,1965$.

29) Kakehashi, S., Baer, P. N. and White, C. : Studies on experimental calculus formation in the rat. VII. Effect of selective desalivation of the major salivary gland. J. Periodont., $35: 467,1964$.

30) Hugoson, A. and Persson, G. : The influence of partial desalivation on periodontal conditions in the white rats. Odont. Tidskr., 74 : 114, 1966.

31) Eilberg, R. G., Gould, D. and Sobel, A. E. : Nucreating substance(s) in human saliva. Nature, 207 : 304, 1965. 